\title{
Prediksi Arus Kas Masa Depan Melalui Persistensi Laba Dan Komponen Akrual
}

\author{
Muhamad Safiq ${ }^{1}$, Ina Yustina ${ }^{2}$, Karinna Firdiastella ${ }^{3}$ \\ ${ }^{1}$ Sekolah Tinggi Ilmu Ekonomi Indonesia - Jakarta \\ 2 President University \\ ${ }^{3}$ Sekolah Tinggi Ilmu Ekonomi Indonesia - Jakarta
}

\begin{abstract}
Abstrak
Penelitian ini bertujuan memprediksi arus kas masa depan melalui persistensi laba dan komponen akrual neraca yang terdiri atas perubahan piutang, perubahan persediaan, dan perubahan hutang pada perusahaan manufaktur yang terdaftar di Bursa Efek Indonesia (BEI). Data yang digunakan dalam penelitian ini berupa data panel, mulai tahun 2011 sampai dengan tahun 2015 dengan jumlah perusahaan sebanyak 58 perusaahaan manufaktur, sehingga total observasi dalam penelitian ini sebanyak 290 data observasi. Pengujian hipotesis dalam penelitian ini menggunakan pendekatan OLS dengan alat analisis Eview 9. Adapun, hasil penelitian ini menunjukkan bahwa persistensi laba berpengaruh positif terhadap arus kas masa depan, namun komponen akrual neraca yang terdiri atas perubahan piutang, perubahan persediaan dan perubahan hutang hanya berpengaruh secara parsial. Sedangkan, secara simultan tidak berpengaruh terhadap arus kas masa depan. Uji tambahan menunjukkan bahwa perubahan persediaan dengan perubahan hutang berpengaruh positif terhadap arus kas masa depan, sementara perubahan piutang dengan perubahan persediaan tidak berpengaruh terhadap arus kas masa depan. Sebaliknya, perubahan piutang dengan perubahan hutang berpengaruh positif terhadap arus kas masa depan.
\end{abstract}

Kata Kunci: Persistensi Laba, Komponen Akrual Neraca, Arus Kas Masa Depan

\begin{abstract}
This study aims to develop the beliefs and components of accruals related to the components that exist, at the same time in the Indonesia Stock Exchange (BEI). The data used in this research is panel data, from 2011 until 2015 with the number of companies as much as 58 manufacturing companies, totality of data in this industry as much as 290 data. Hypothesis testing in this research using OLS approach with analysis tool. Eviews 9. As for, the results of this study indicate that the persistence of positive spiders on the future, but the relevant accrual components that arise during this time. . Meanwhile, simultaneous does not reflect future cash futures. An alternative test resulted in a positive relationship to future cash flows, where responsibility would not happen to the future. Here, diseminahkan, donated by positive to the future.
\end{abstract}

Keywords: Profit Persistence, Accrual Balance Components, Future Cash Flows

\section{A. Pendahuluan}

Para pelaku bisnis menuntut adanya informasi yang tepat dan akurat sebagai dasar pengambilan keputusannya. Informasi yang tepat dan akurat sangat berguna bagi para pelaku bisnis dalam mempertimbangkan alternatif-alternatif strategi dalam bisnisnya. Prediksi atas 
kondisi masa yang akan mendatang memberikan arah operasi usaha dalam ketidakpastian yang dihadapi oleh perusahaan. Dimana ketidakpastian yang timbul akan mempengaruhi kelangsungan hidup perusahaan dimasa mendatang. Dalam hal ini, manajemen membutuhkan informasi mengenai kondisi keuangan (laporan posisi dan kinerja keuangan) sebagai media yang dapat digunakan untuk menggambarkan masa depan perusahaan.

Informasi yang ada dalam laporan keuangan merupakan informasi penting bagi para penggunanya dalam membuat suatu keputusan ekonomi. Kemampuan para pelaku ekonomi dalam memprediksi kondisi keuangan perusahaan masa depan sangat diperlukan sebelum membuat suatu keputusan ekonomi. Jenis keputusan yang dibuat oleh pengguna laporan keuangan sangat bervariasi, tergantung pada metode pengambilan keputusan, informasi yang dimiliki dari sumber lain, dan kemampuan mereka dalam memperoleh informasi.

Berdasarkan tujuan laporan keuangan yaitu menyediakan informasi yang bermanfaat untuk menilai prospek aliran kas perusahaan, maka informasi tentang posisi dan kinerja keuangan sangat diperlukan. Hal ini mengindikasikan bahwa arus kas perusahaan juga bagian dari penilaian performa suatu perusahaan ynag tidak kalah penting. Kesalahan yang sering terjadi adalah adanya anggapan bahwa jika pendapatan (laba) naik atau meningkat, maka performa perusahaan juga ikut bagus. Asumsi tersebut akan menjebak pemikiran para pelaku ekonomi dalam menilai performa suatu perusahaan. Karena jika perusahaan profitabilitasnya baik namun mengalami defisit arus kas, dapat mengindikasi bahwa perusahaan mengalami masalah keuangan (financial distress) dan dikhawatirkan tidak mampu melunasi kewajibannya, khususnya terhadap kreditor maupun membayar deviden kepada investor.

Untuk itu, pengelolaan arus kas yang baik merupakan kunci keberlangsungan dalam sebuah usaha, karena segala aktivitas operasional perusahaan sangat bergantung pada arus kas. Selanjutnya, agar bisnis dapat berjalan dengan baik, setidaknya perusahaan harus dapat menjaga keseimbangan antara penerimaan dan pengeluaran kas.

Prediksi arus kas masa depan perusahaan merupakan suatu isu fundamental dalam keputusan bisnis, informasi ini mempengaruhi nilai sekuritas perusahaan yang tergantung pada kemampuan perusahaan dalam menghasilkan arus kas. Penyajian pelaporan arus kas suatu perusahaan sangat penting bagi para pengguna laporan ekonomi. PSAK No. 2 tahun 2015 menyatakan bahwa laporan arus kas dapat menyediakan informasi yang memungkinkan pengguna untuk mengevaluasi perubahan dalam asset netto entitas, struktur keuangannya (termasuk likuiditas dan solvabilitas) dan kemampuannya untuk mempengaruhi jumlah serta waktu arus kas dalam rangka penyesuaian terhadap keadaan dan peluang yang berubah. Informasi arus kas berguna untuk menilai kemampuan entitas dalam menghasilkan kas dan setara kas dan memungkinkan pengguna mengembangkan model untuk menilai dan membandingkan nilai kini arus kas masa depan dari berbagai entitas.

Penelitian mengenai prediksi arus kas masa depan telah dilaporkan peneliti terdahulu Beberapa peneliti terdahulu menguji pengaruh kemampuan laba dalam memprediksi arus kas masa depan, hasilnya menunjukkan bahwa laba memiliki pengaruh yang signifikan dalam memprediksi arus kas masa depan, seperti penelitian yang dilakukan oleh Sulistyawan dan Septiani (2015). Selanjutnya, Ebaid (2011) mendokumentasikan adanya pengaruh komponen akrual terhadap arus kas masa depan. Hasil tersebut menyatakan bahwa perubahan piutang, perubahan persediaan, perubahan hutang berpengaruh dan perubahan depresiasi berpengaruh 
signifikan dalam memprediksi arus kas masa depan, sebagaimana yang dilaporkan Sulistyawan dan Septianti (2015).

Namun Triyono (2011) menunjukkan hasil yang berbeda, yang mana komponen akrual yang terdiri dari perubahan piutang, perubahan persediaan, perubahan hutang, depresiasi dan akrual lainnya serta laba (Andayani dan Wirajaya, 2012) tidak berpengaruh signifikan dalam memprediksi arus kas masa depan. Hal ini memotivasi peneliti untuk menguji lebih lanjut hasil penelitian tersebut.

Selanjutnya, untuk memprediksi arus kas masa depan, penulis menggunakan persistensi laba dan komponen akrual neraca (perubahan piutang, perubahan persediaan dan perubahan hutang). Hal itu didorong oleh dugaan bahwa laba yang persisten atau laba yang cenderung tidak berfluktuatif dapat mencerminkan keberlanjutan laba dimasa depan dan berkesinambungan untuk periode yang lama. Persistensi laba menjadi penting karena investor memiliki kepentingan kinerja perusahaan dimasa depan. Oleh karena itu, peneliti memiliki 2 hal penting yang berkaitan dengan prediksi arus kas masa depan yaitu pertama, apakah persistensi laba berpengaruh terhadap arus kas masa depan, kedua apakah komponen akrual neraca berpengaruh terhadap arus kasmasa depan?

\section{B. Tinjauan Teoritis}

\section{Signalling Theory}

Teori sinyal (signalling theory) yang diperkenalkan George Akerlof (1970) dalam karyanya "The Market for Lemons", yang memperkenalkan istilah informasi asimetris (assymetri information). Akerlof mempelajari fenomena ketidakseimbangan informasi mengenai kualitas produk antara pembeli dan penjual, dengan melakukan pengujian terhadap pasar mobil bekas (used car). Selanjutnya, Akerlov mendokumentasikan bahwa ketika pembeli tidak memiliki informasi terkait spesifikasi produk dan hanya memiliki persepsi umum mengenai produk tersebut, maka pembeli akan menilai semua produk pada harga yang sama, baik produk yang berkualitas tinggi maupun yang berkualitas rendah, sehingga merugikan penjual produk berkualitas tinggi. Kondisi dimana salah satu pihak (penjual) yang melangsungkan transaksi usaha memiliki informasi lebih atas pihak lain (pembeli) ini disebut adverse selection (Scott, 2009). Menurut Akerlov (1970), adverse selection dapat dikurangi apabila penjual mengkomunikasikan produk mereka dengan memberikan sinyal berupa informasi tentang kualitas produk yang mereka miliki.

Kemudian, Spence (1973) mengembangkan pemikiran Akerlov (1970) tersebut dalam sebuah model keseimbangan sinyal (basic equilibrium signaling model). Spence memberikan ilustrasi pada pasar tenaga kerja (job market) dan mengemukakan bahwa perusahaan yang memiliki kinerja yang baik (superiorperformance) menggunakan informasi finansial untuk mengirimkan sinyal ke pasar. Dari penelitiannya tersebut, Spence (1973) juga menemukan bahwa cost ofsignal pada bad news lebih tinggi dari pada good news dan perusahaan yang memiliki bad news mengirimkan sinyal yang tidak kredibel. Hal tersebut memotivasi manajer untuk mengungkapkan informasi private untuk mengurangi asimetri informasi dengan harapan dapat mengirimkan sinyal yang baik (goodnews) tentang kinerja perusahaan ke pasar. 
Para pemakai laporan keuangan, selanjutnya, memanfaatkan sebanyak-banyaknya informasi yang diperoleh dari laporan keuangan yang dipublikasikan. Informasi tersebut digunakan sebagai salah satu tolak ukur untuk menilai kinerja perusahaan dan berspekulasi terhadap keuangan perusahaan di masa yang akan datang. Hal pertama yang dilihat dari laporan keuangan adalah nilai kas dan laba yang dihasilkan selama periode bersangkutan. Karena keberhasilan perusahaan dapat dilihat dari seberapa besar perolehan laba dan arus kas yang dimiliki untuk menjalankan kegiatan operasionalnya. Kinerja perusahaan yang dinilai melalui profitabilitas (laba) menjadi pusat perhatian penting karena laba yang berkualitas akan mencerminkan keberlanjutan di masa depan.

Pengguna informasi tentunya mengharapkan laba yang persisten, karena persistensi laba menunjukkan "the likelihood of earnings levels will recur in future periods" atau "kemungkinan bahwa tingkat laba akan terulang dalam periode-periode mendatang"(Nichols dan Wahlen, 2004: 265). Persistensi laba untuk kelompok sampel tertentu dapat berbeda dengan persistensi laba untuk kelompok sampel yang lain. Persistensi laba penting bagi investor dalam penilaian saham dan selanjutnya dalam pengambilan keputusan investasi pada saham tersebut. Oleh sebab itu, diperlukan sinyal yang dapat membedakan persistensi laba untuk masing-masing kelompok tersebut.

\section{Laporan Keuangan}

Menurut Pernyataan Standar Akuntansi Keuangan No.1 (2015: 2) mengatakan bahwa "Laporan keuangan merupakan bagian dari proses pelaporan keuangan. Laporan keuangan yang lengkap biasanya meliputi neraca, laporan labarugi, laporan perubahan posisi keuangan (yang dapat disajikan dalam berbagai cara misalnya, sebagai laporan arus kas, atau laporan arus dana),catatan dan laporan lain serta materi penjelasan yang merupakan bagian integral dari laporan keuangan. Disamping itu juga termasuk skedul dan informasi tambahan yang berkaitan dengan laporan tersebut, misalnya,informasi keuangan segmen industri dan geografis serta pengungkapan pengaruh perubahan harga".

Sedangkan, Kieso dkk (2007:2) memberi pengertian laporan keuangan adalah sebagai berikut. "Laporan keuangan merupakan sarana yang bisa digunakan oleh entitas untuk mengkomunikasikan keadaan terkait dengan kondisi keuangannya kepada pihak-pihak yang berkepentingan baik yang berasal dari internal entitas maupun eksternal entitas". Definisi tersebut mengandung arti bahwa laporan keuangan merupakan gambaran atas kondisi keuangan dan kinerja suatu perusahaan, sehingga pihak-pihak yang berkepentingan didalamnya dapat membuat suatu keputusan bisnis.

Adapun tujuan laporan keuangan menurut Pernyataan Standar Akuntansi Keuangan (PSAK) No.1 Paragraf ke 7 (Revisi 2009) menjelaskan bahwa tujuan laporan keuangan adalah memberikan informasi mengenai posisi keuangan, kinerja, serta arus kas entitas yang bermanfaat bagi sebagian besar kalangan pengguna laporan dalam pembuatan keputusan ekonomi. Laporan keuangan juga menunjukkan hasil pertanggungjawaban manajemen atas penggunaan sumber daya perusahaan.

Untuk mencapai tujuan tersebut, laporan keuangan menyajikan informasi mengenai entitas meliputi : asset, liabilities, ekuitas, pendapatan dan beban termasuk keuntungan dan kerugian, kontibusi dari dan distribusi kepada pemilik dalam kapasitasnya sebagai pemilik dan arus kas. Informasi tersebut dan informasi lainnya yang ada dalam catatan atas laporan keuangan, 
dapat membantu pengguna laporan keuangan dalam memprediksi arus kas masa depan khususnya dalam hal waktu dan kepastiasn diperolehnya kas dan setara kas.

\section{Arus Kas dan Setara Kas}

Menurut PSAK No.2 Tahun 2009 (paragraf 43), mengharuskan perusahaan untuk mengungkapkan komponen kas dan setara kas serta harus menyajikan rekonsiliasi jumlah tersebut dalam laporan arus kas dengan pos yang sama dengan pos yang ada di neraca. PSAK No. 2 Tahun 2009 menjelaskan bahwa kas terdiri dari saldo kas (cash on hand) dan rekening giro. Setara kas (cash equivalent) adalah investasi yang sifatnya sangat likuid, berjangka pendek dan yang dengan cepat dapat dijadikan kas dalam jumlah tertentu tanpa menghadapi risiko perubahan nilai yang signifikan. Arus kas adalah arus masuk dan arus keluar kas atau setara kas.

Dalam Statement of Financial Accountuing Standars no. 95, FASB menyatakan bahwa suatu laporan arus kas harus menjelaskan selisih yang terjadi antara saldo awal dan saldo akhir serta setara kas (cash equivalent). Hal ini berarti dalam laporan kas, kas memiliki pengertian yang lebih luas yang tidak hanya terbatas pada saldo kas tersedia di perusahaan (cash on hand) dan kas di bank, tetapi juga termasuk perkiraan-perkiraan yang dikenal sebagai setara kas (cash equivalent).

Laporan arus kas menyajikan dasar analisis dinamis yang berpusat pada periode perubahan kondisi keuangan akibat keputusan yang diambil selama periode tertentu (H.A. Erich, 1997). Laporan arus kas merupakan laporan yang menyajikan informasi tentang jumlah arus kas masuk dan arus kas keluar atau sumber dan pemakaian kas dalam suatu perusahaan.

Laporan arus kas harus melaporkan arus kas selama periode tertentu dan diklasifikasikan menurut aktivitas operasi, invests, dan pendanaan (PSAK No.2, revisi 2009, paragraf 10). Entitas menyajikan arus kas dari aktivitas operasi, investasi, dan pendanaan dengan cara yang paling sesuai dengan bisnis entitas tersebut. Klasifikasi menurut aktivitas memberikan informasi yang memungkinkan para pengguna laporan untuk menilai pengaruh aktivitas tersebut terhadap posisi keuangan entitas serta terhadap jumlah kas dan setara kas. Selanjutnya, dalam PSAK No.2, paragraf 49 (1995:2,4), dinyatakan bahwa laporan arus kas harus melaporkan arus kas selama periode tertentu dan diklasifikasikan menurut aktifitas operasi, investasi, dan pendanaan.

\section{Laba dan Persistensi Laba}

Laba adalah kenaikan modal (aktiva bersih) yang berasal dari transaksi sampingan atau transaksi yang jarang terjadi dari badan usaha dan dari semua transaksi atau kejadian lain yang mempengaruhi badan usaha selama suatu periode, kecuali yang termasuk dari pendapatan (revenue) atau investasi pemilik (Zaky Baridwan, 2004:29). Pengertian laba secara umum adalah selisih dari pendapatan di atas biaya-biayanya dalam jangka waktu (periode) tertentu. Laba sering digunakan sebagai suatu dasar untuk pengenaan pajak, kebijakan deviden, pedoman investasi serta pengambilan keputusan dan unsur prediksi (Harnanto, 2003 :444).

Penghasilan bersih (laba) sering digunakan sebagai ukuran kinerja atau sebagai dasar bagi ukuran yang lain seperti imbalan investasi (return of investment) atau penghasilan per saham (earning per share). Unsur yang langsung berkaitan dengan pengukuran penghasilan bersih 
(laba) adalah penghasilan dan beban. Penghasilan (income) adalah kenaikan manfaat ekonomi selama suatu periode akuntansi dalam bentuk pemasukan atau penambahan aktiva atau penurunan kewajiban yang menyebabkan kenaikan ekuitas yang tidak berasal dari kontribusi penanaman modal. Beban (expenses) adalah penurunan manfaat ekonomi selama suatu periode akuntansi dalam bentuk arus keluar atau berkurangnya aktiva atau terjadinya kewajiban yang mengakibatkan penurunan ekuitas yang tidak menyangkut pembagian kepada penanam modal.

Menurut Waren et. al. (2011:300) menyatakan bahwa "Laporan laba rugi melaporkan pendapatan dan beban selama periode waktu tertentu berdasarkan konsep penandingan”. Konsep ini diterapkan dengan menandingkan beban dengan pendapatan yang dihasilkan selama periode terjadinya beban tersebut. Laporan laba rugi juga melaporkan kelebihan pendapatan terhadap beban-beban yang terjadi yang disebut dengan laba bersih. Sebaliknya, jika beban melebihi pendapatan, maka disebut rugi bersih. Selanjutnya menurut Wild et. al. (2006:300) menyatakan bahwa laba dinyatakan sebagai berikut berikut. "Laba ditentukan dengan menggunakan dasar akrual (accrual basis) dalam akuntansi. Dalam akuntansi akrual, pendapatan diakui saat perusahaan menjual barang atau menyerahkan jasa, terlepas saat diterimanya kas. Demikian juga dengan beban, pengakuannya sama dengan pendapatan, terlepas dari pembayaran kas". Dengan demikian, laba dapat ditentukan melalui selisih antara pendapatan dan beban dari kegiatan usaha. Oleh karena itu, kelayakan penentuan pelaporan laba atau rugi dengan menentukan jumlah pendapatan yang dihasilkan dan jumlah beban yang dikeluarkan dalam periode yang bersangkutan.

Sedangkan, persistensi laba merupakan laba yang dapat digunakan sebagai indikator future earnings. Persistensi laba didefinisikan sebagai laba yang dapat digunakan sebagai pengukur laba itu sendiri. Artinya, laba saat ini dapat digunakan sebagai indikator laba periode mendatang (future earnings). Scott (2009) menyatakan bahwa persistensi laba sebagai "revisi laba yang diharapkan di masa mendatang (expected future earnings) yang diimplikasikan oleh inovasi laba tahun berjalan sehingga persistensi laba dilihat dari inovasi laba tahun berjalan yang dihubungkan dengan perubahan harga saham. Besarnya revisi ini menunjukkan tingkat persistensi laba”. Penman (2009:238) mengungkapkan bahwa persistensi laba adalah "revisi dalam laba akuntansi yang diharapkan di masa mendatang yang disebabkan oleh inovasi laba tahun berjalan. Persistensi laba tersebut ditentukan oleh komponen akrual dan aliran kas yang terkandung dalam laba saat ini”.

Selanjutnya, Subramanyam (2014) mengatakan bahwa sebuah analisis keuangan yang baik diidentifikasikan dari komponen laba yang stabil dan dapat diperkirakan atau disebut dengan persisten. Analisis persistensi laba ini membantu dalam memperkirakan kepercayaan produktif kekuatan dalam penilaian laba. Perusahaanharus waspada terhadap manajemen laba dan perataan laba. Manajemen laba dan perataan laba dapat menggambarkan stabilitas dan prediktibilitas dari laba. Manajemen perusahaan sering menegaskan bahwa kegiatan seperti menghapus distorsi atau keanehan dari hasil operasi, namun kegiatan ini dapat menutupi penyimpangan siklus lingkungan dan pengalaman perusahaan. Persistensi laba ini penting bagi pengguna laporan keuangan dalam menilai resiko perusahaan.

\section{Komponen-komponen Akrual}


Subramanyam dan Wild (2010) mendefinisikan bahwa akrual merupakan jumlah penyesuaian akuntansi yang membuat laba bersih berbeda dengan arus kas bersih. Dari penyesuaian ini mengakibatkan pengaruh terhadap laba dan tidak berdampak pada arus kas, karena penggunaan jurnal berpasangan dengan konsep akrual yang juga mempengaruhi neraca yang melalui peningkatan dan penurunan aset atau kewajiban dalam jumlah yang sama. DSAKIAI dalam PSAK paragraf 25 revisi 2009 menyebutkan bahwa entitas menyusun laporan keuangan atas dasar akrual, kecuali laporan arus kas. Ketika akuntansi berbasis akrual digunakan, entitas mengakui pos-pos sebagai asset, liabilitas, ekuitas, pendapatan dan beban (unsur-unsur laporan keuangan) ketika pos-pos tersebut memenuhi definisi dan kriteria pengakuan untuk unsur-unsur tersebut dalam Kerangka Dasar Penyusunan dan Penyajian Laporan Keuangan (PSAK, revisi 2009, paragraf 26).

Barth, et al. (2001) dalam Thiono (2006) yang membuktikan bahwa laba disaggregat menjadi akrual dan arus kas utama komponen yaitu perubahan piutang dan utang, persediaan, depresiasi, amortisasi, dan akrual lainnya secara signifikan meningkatkan laba untuk memprediksi arus kas masa depan.

\section{PENGEMBANGAN HIPOTESIS}

\section{Persistensi Laba dan Arus Kas Masa Depan}

Laba sebagai salah satu komponen laporan keuangan perusahaan merupakan informasi yang sangat penting, baik bagi pihak internal maupun pihak eksternal perusahaan. Persistensi laba menjadi perhitungan lain dalam pengambilan keputusan. Laba akuntansi yang persisten adalah laba akuntansi yang memiliki sedikit atau tidak mengandung akrual dan dapat mencerminkan kinerja keuangan perusahaan yang sesungguhhnya (Chandarin, 2003). Hayn (1995) mengatakan bahwa gangguan dalam laba akuntansi disebabkan peristiwa transitori (Transitory events) atau penerapan konsep akrual dalam akuntansi, semakin besar akrual maka semakin rendah persistensi laba. Perusahaan dengan akrual yang besar akan memiliki persistensi laba yang lebih rendah sehingga mengalami penurunan kinerja laba pada tahun berikutnya. Oleh karena itu, hipotesis pertama penelitian ini dapat dinyatakan sebagai berikut.

\section{$\mathrm{H}_{1}$ : Laba yang persisten berpengaruh positif terhadap arus kas masa depan.}

\section{Komponen Akrul Neraca dan Arus Kas Masa Depan}

Teori sinyal menjelaskan bahwa dalam pelaporan keuangan seringkali terjadi sebuah asimetri informasi. Hal tersebut terjadi karena tindakan manipulasi berupa manajemen laba yang mungkin saja dilakukan oleh pihak manajemen perusahaan, agar laba terlihat tinggi dan ditangkap sebagai sinyal bahwa perusahaan dalam kondisi yang baik secara financial. Komponen akrual neraca yang terdiri atas perubahan piutang, perubahan persediaan dan perubahan hutang dianggap lebih mampu memenuhi kebutuhan informasi yang diinginkan oleh investor jika dibandingkan laba. Pendapat tersebut muncul karena laba akuntansi sangat rentan untuk dimanipulasi dan adanya perubahan-perubahan metode akuntansi yang digunakan. Untuk itu komponen akrual neraca dianggap lebih baik dibandingkan laba dalam memprediksi arus kas masa depan. Prayoga (2012) menunjukkan bahwa perubahan piutang berpengaruh signifikan dalam memprediksi arus kas opersi masa depan. Selain piutang, komponen akrual yang mempengaruhi arus kas aktivitas operasi adalah persediaan. Menurut 
PSAK No. 14 Tahun 2009, persediaan merupakan aktiva yang tersedia untuk dijual dalam kegiatan usaha, dalam proses produksi, atau dalam bentuk bahan perlengkapan untuk digunakan dalam proses produksi atau pemberian jasa. Perubahan persediaan menggambarkan bahwa terjadi peningkatan dan penurunan dalam penjualan, sehingga mempengaruhi aliran arus kas masuk pada aktivitas operasi di masa depan pada saat pendapatan tersebut diterima. Dalam penelitiannya Sulistyawan dan Septianti (2015) membuktikan bahwa komponen akrual yaitu persediaan berpengaruh signifikan dalam memprediksi arus kas operasi dimasa depan.

Komponen akrual lainnya adalah hutang yang timbul dari transaksi pembelian secara kredit yang memberikan manfaat di masa mendatang. Hutang dapat mempengaruhi arus kas operasi di masa depan ketika perusahaan membayar atau melunasi hutang tersebut, sehingga menimbulkan arus kas keluar dan mengurangi arus kas aktivitas operasi di masa depan. Penelitian Ibrahim El-Sayed Ebaid (2011) yang mengembangkan penelitian dari (Barth et al, 2001); Dechow et al. 1998) menggunakan komponen perubahan piuatang usaha, perubahan utang usaha, dan perubahan persediaan dalam menguji kemampuan komponen akrual tersebut terhadap arus kas operasi di masa mendatang. Hasilnya membuktikan bahwa komponen akrual yaitu perubahan hutang usaha berpengaruh signifikan dalam memprediksi arus kas operasi dimasa depan. Selanjutnya, hipotesis kedua dalam penelitian ini dapat dinyatakan sebagai berikut.

\section{$\mathrm{H}_{2}$ : Komponen akrul neraca berpengaruh positif terhadap arus kas masa depan.}

\section{Metode Penelitian}

Penelitian menggunakan data kuantitatif dari berbagai perusahaan manufaktur yang terdaftar di bursa efek Indonesia dengan menggunakan analisis regresi data panel. Data panel merupakan gabungan antara data runtut waktu (time series) dan data silang antar perusahaan (cross section). Penelitian ini bertujuan untuk menguji variabel persistensi laba dan komponen akrual neraca terhadap variabel dependen (Y) yaitu arus kas masa depan. Adapun besaran sampel ditentukan berdasarkan metode purposive sampling, sementara data diperoleh dari www.idx.co.id.

\section{Definisi dan Operasionalisasi Variabel}

\section{Persistensi Laba $\left(\mathbf{X}_{1}\right)$}

Laba yang semakin persisten menunjukkan laba yang semakin informatif. Sebaliknya, jika laba kurangpersisten maka laba menjadi kurang informatif (Tucker dan Zarowin, 2006). Beberapa cara pengukuran persistensi laba menurut beberapa ahli seperti Lipe (1990) dan Sloan (1996) menggunakan koefisien regresi dari regresi antara laba akuntansi perioda sekarang dengan perioda yang akan datang sebagai proksi persistensi laba akuntansi. Berdasarkan Francis et al.(2004) mengukur persistensi laba dari slope koefisien hasil regresi current earnings pada lagged earnings. Penelitian ini menggunakan koefisien regresi dari regresi antara laba periode sekarang dengan periode yang akan datang, sebagai proksi persistensi laba akuntansi. Hal ini mengacu pada penelitian Lipe (1990) yang diukur sebagai berikut.

Keterangan :

$$
\mathbf{E}_{\mathrm{it}}=\boldsymbol{\beta}_{\mathbf{0}}+\boldsymbol{\beta}_{\mathbf{1}} \mathbf{E}_{\mathrm{it}-1}+\mathcal{E}
$$


$\mathrm{E}_{\mathrm{it}} \quad$ :Laba bersih perusahaan i pada tahun $\mathrm{t}$

$\beta_{0} \quad$ :konstanta

$\beta_{1} \quad$ :Persistensi Laba

$\mathrm{E}_{\mathrm{it}-1} \quad$ :Laba bersih perusahaan i sebelum tahun $\mathrm{t}$

Apabila koefisien regresi laba akuntansi $(\beta 1)>1$ hal ini menunjukkan bahwa laba perusahaan adalah high persisten. Apabila koefisien regresi laba $(\beta 1)>0$ hal ini menunjukkan bahwa laba perusahaan tersebut persisten. Sebaliknya, apabila koefisien regresi laba $(\beta 1) \leq 0$ berarti laba perusahaan fluktuatif dan tidak persisten. (Francis, at al.2004)

\section{Komponen-Komponen Akrual Neraca $\left(\mathbf{X}_{2}\right)$}

Komponen-komponen akrual yang digunakan oleh peneliti diperoleh dari laporan keuangan konsolidasi pada tahun amatan atau pada periode t. Komponen-komponen akrual neraca terdiri dari perubahan piutang usaha, perubahan hutang usaha, dan perubahan persediaan.

a. Perubahan Piutang Usaha $(\triangle \mathrm{AR})$

Perubahan piutang usaha diperoleh dari selisih piutang usaha tahun berikutnya dengan tahun amatan atau pada periode t dari laporan keuangan.(Ebaid, 2011) yang diukur sebagai berikut.

$$
\triangle \mathrm{AR}=\frac{\mathrm{AR}_{\mathrm{t}}-\mathrm{AR}_{\mathrm{t}-1}}{\mathrm{TA}_{\mathrm{t}}}
$$

b. Perubahan Utang Usaha ( $\triangle \mathrm{AP}$ )

Perubahan hutang usaha diperoleh dari selisih hutang usaha tahun berikutnya dengan tahun amatan atau pada periode t pada laporan keuangan.(Ebaid, 2011) yang diukur sebagai berikut.

$$
\triangle \mathrm{AP}=\frac{\mathrm{AP}_{\mathrm{t}}-\mathrm{AP}_{\mathrm{t}-1}}{\mathrm{TA}_{\mathrm{t}}}
$$

c. Perubahan Persediaan $(\triangle \mathrm{PRSD})$

Perubahan persediaan diperoleh dari selisih persediaan tahun berikutnyadengan tahun amatan atau pada periode t pada laporan keuangan. (Ebaid, 2011) yang diukur sebagai berikut.

$$
\triangle \mathrm{PRSD}=\underline{\mathrm{PRSD}_{\mathrm{t}}-\mathrm{PRSD}_{\mathrm{t}-1}}
$$

TA

\section{Arus kas masa depan (Y)}

Pengukuran variabel arus kas operasi dapat dituliskan sebagai berikut.

$$
\mathrm{AKMD}=\frac{\mathrm{AKO}_{\mathrm{t}+1}}{\mathrm{TA}_{\mathrm{t}+1}}
$$

Keterangan :

AKMD : Arus kas masa depan

$\mathrm{AKO}_{\mathrm{t}+1}$ : Arus kas operasi periode $\mathrm{t}+1$

$\mathrm{TA}_{\mathrm{t}+1}:$ Total Aset perode $\mathrm{t}+1$ 


\section{Sampel Penelitian}

Metode yang digunakan dalam pemilihan sampel objek penelitian ini adalah purposive sampling, yaitu metode pemilihan objek dengan beberapa kriteria tertentu. Kriteria yang dimaksudkan yaitu pertama, perusahaan jasa yang terdaftar pada Bursa Efek Indonesia (BEI) yang menyediakan laporan keuangan selama periode 2011-2016, 2) mengungkapkan dan menyajikan secara lengkap data yang dibutuhkan dalam penelitian selama periode tahun 2011-2016 secara berturut-turut, 3) Perusahaan tidak mengalami kerugian atau laba bersih tidak negatif, 4) Laporan keuangan disajikan dengan mata uang Rupiah, dan terakhir, laporan keuangan tahunan disajikan dalam periode yang berakhir pada 31 Desember.

\section{Alat Analisis - Regresi Data Panel}

Metode yang digunakan dalam penelitian ini adalah regresi data panel. Data panel atau pooled data merupakan kombinasi dari data time series dan cross section. Analisis regresi data panel adalah analisi regresi untuk mengamati hubungan antar variabel terikat (dependant variabel) dengan satu atau lebih variabel bebas (independent variabel). Data yang digunakan dalam penelitian ini yaitu berupa gabungan data time series (2011-2015) dan cross section (58 sampel perusahaan). Dalam menganalisis variabel yang mempengaruhi arus kas masa depan digunkan model :

$\begin{array}{ll}\text { AKMD }=\boldsymbol{\beta}_{\mathbf{0}}+ & \boldsymbol{\beta}_{\mathbf{1}} \mathbf{P L}+\boldsymbol{\beta}_{\mathbf{2}} \mathbf{K A N}(\triangle \mathbf{A R}+ \\ \text { Keterangan: } & \\ \text { AKMD } & : \text { Arus kas masa depan } \\ \text { PSL } & : \text { Persistensi Laba } \\ \text { KAN } & : \text { Komponen Akrual Neraca } \\ \triangle \text { AR } & : \text { Perubahan Piutang Usaha } \\ \triangle \text { AP } & : \text { Perubahan Utang Usaha } \\ \triangle \text { PRSD } & : \text { Perubahan Persediaan } \\ \mathrm{B}_{0} & : \text { Konstanta } \\ \mathrm{B}_{1,2} & : \text { Koefisiensi regresi } \\ \varepsilon & : \text { Error }\end{array}$

\section{Model Estimasi Common Effect}

Model estimasi Common Effect merupakan teknik estimasi yang paling sederhana untuk mengestimasi data panel dengan cara hanya mengkombinasikan data time series dan cross section (Winarno, 2011:9). Model ini hanya menggabungkan kedua data tanpa melihat perbedaan antar waktu dan individu sehingga dapat dikatakan bahwa model ini sama dengan metode OLS (Ordinary Least Square) karena menggunakan kuadrat kecil biasa. Dalam pendekatan ini diasumsikan bahwa data antar perusahaan sama dalam berbagai kurun waktu.

\section{Model Estimasi Fixed Effect}

Teknik model fixed effect adalah teknik mengestimasi data panel menggunakan variabel dummy untuk mengungkapkan adanya perbedaan karakter diantara objek penelitian. Efek 
tetap disini maksudnya adalah bahwa satu objek memiliki konstanta yang tetap besarnya untuk berbagai periode waktu. Demikian juga dengan koefisien regresinya, besarnya tetap dari waktu ke waktu (tima invariant). Untuk membedakan satu objek dengan objek lainnya, digunakan variabel semu. Oleh karena itu, model ini sering juga disebut dengan Least Square Dummy Variables dan disingkat LSDV. (Winarno, 2011: 9).

\section{Model Estimasi Random Effect}

Efek random digunakan untuk mengatasi kelemahan metode efek tetap yang menggunakan variabel semu, sehingga model mengalami ketidak pastian. Tanpa menggunakan variabel semu, metode random efek menggunkan residual, yang diduga memiliki hubungan antar waktu dan antar objek penelitian. Dalam model efek acak (random effect), parameterparameter yang berbeda antar perusahaan maupun antar waktu dimasukkan dalam error. Karena hal inilah, model efek acak juga disebut dengan model komponen eror (eror component model). Sehingga dapat membantu mengestimasi data panel dimana variabel gangguan mungkin saling berkaitan antar waktu dan antar individu. (Winarno, 2011: 9).

Keputusan pemakaian model fixed effect ataupun random effect ditentukan dengan uji Hausaman. Uji Hausman didasarkan pada ide bahwa kedua metode OLS dan GLS konsisten, tetapi OLS tidak efisien dalam hipotesis nol. Dipihak lain, hipotesis alternatifnya adalah metode OLS dana metode GLS tidak konsisten. Statistik uji Hausman mengikuti distribusi chi square dengan degree of freedom sebanyak $\mathrm{K}$, dimana $\mathrm{K}$ adalah jumlah variabel independent. Jika hipotesis nol ditolak, maka model yang digunakan adalah model fixed effect, sedangkan jika hipotesis nol diterima, maka model yang digunakan adalah model random effect.

\section{Hasil Penelitian dan Pembahasan}

\section{Analisis Statistik Deskriptif}

Penelitian ini menggunakan analisis deskriptif yang berfungsi untuk menganalisis data dengan cara mendeskripsikan atau menggambarkan data yang telah terkumpul sebagaimana adanya tanpa bermaksud membuat kesimpulan yang berlaku untuk umum atau generalisasinya (Sugiyono, 2015:207). Analisis deskripsi ini meliputi table rata-rata (mean), standar deviasi, nilai maksimum, nilai minimum dan jumlah penelitian. Selain itu juga disajikan tabel distribusi frekuensi dengan melakukan pengkategorian terhadap nilai masingmasing indikator.

\section{Tabel 1 Hasil Analisis Deskriptif}

Arus Kas Masa Depan Persistensi Laba $\begin{gathered}\text { Komponen } \\ \text { Akrual Neraca }\end{gathered}$

$\begin{array}{llll}\text { Mean } & 0.109603 & 1.086474 & 0.251195 \\ \text { Median } & 0.090483 & 0.927486 & 0.166446 \\ \text { Maximum } & 0.799247 & 4.613069 & 3.054890\end{array}$




$\begin{array}{llll}\text { Minimum } & -0.291265 & 0.218015 & -4.306437 \\ \text { Std. Dev. } & 0.127539 & 0.645023 & 0.611640 \\ \text { Skewness } & 1.287413 & 2.493829 & -2.955299 \\ \text { Kurtosis } & 7.643889 & 10.74723 & 30.91190\end{array}$

Sumber: Data yang diolah, 2017

Berdasarkan hasil analisis statistik deskriptif dari tabel diatas menunjukan bahwa variabel Peristensi laba atas Arus Kas Masa Depan yang diteliti memiliki nilai minimum sebesar 0.218015 , nilai maksimum sebesar 4.613069 , nilai mean (rata-rata) 1.086474 dan nilai standar deviasi sebesar 0.645023. Untuk variabel Komponen Akrual Neraca memiliki nilai minimum sebesar -4.306437, nilai maksimum 3.054890, nilai mean (rata-rata) 1.251195 dan nilai standar deviasi sebesar 0.611640. Sedangkan untuk nilai arus kas operasi masa diketahui bahwa nilai rata-ratanya 0.109603. Hal ini menunjukkan bahwa rata-rata perusahaan memanfaatkan arus kas operasi sebesar 0.109603, dengan pemakaian minimum sebesar 0.291265 , pemakaian maksimum sebesar 0.799247 dan standar deviasi 0.127539 .

\section{Evaluasi Model Regresi Data Panel}

Regresi dengan menggunakan data panel disebut dengan regresi data panel. Menurut Widarjono (2013) ada beberapa keuntungan yang diperoleh dengan menggunakan data panel. Pertama, data panel yang merupakan gabungan dua data time series dan cross section mampu menyediakan data yang lebih banyak sehingga degree of freedom yang lebih besar. Kedua, menggabungkan informasi dari data time series dan cross section dapat mengatasi masalah yang timbul sebagai akibat pengurangan variabel.

Regresi data panel dapat dilakukan dengan tiga model yaitu common effect, fixed effect, dan random effect, masing-masing model memiliki kelebihan dan kekuranganya masing-masing. Pemilihan model tergantung pada asumsi yang dipakai oleh peneliti dan pemenuhan syaratsyarat pengolahan data statistik yang benar, sehingga hasilnya dapat dipertanggungjawabkan secara statistik. Oleh karena itu, langkah pertama yang harus dilakukan adalah memilih model yang tepat dari ketiga model yang tersedia. Data panel yang telah dikumpulkan, diregresikan dengan menggunakan model Estimasi Common Effect.

Metode Pooled Least Square (Common Effect) akan dipilih saat tidak terdapat perbedaan diantara data matrix pada dimensi cross section. Model ini mengestimasikan nilai $\alpha$ yang konstan untuk semua dimensi cross section.

Tabel 2. Hasil Regresi dengan menggunakan panel least square model estimate common effect 


\begin{tabular}{lrlrr}
\hline - Variable & Coefficient & Std. Error & t-Statistic & Prob. \\
\hline C & 0.157643 & 0.014632 & 10.77424 & 0.0000 \\
PL & -0.038750 & 0.011366 & -3.409301 & 0.0007 \\
\multicolumn{1}{c}{ KAN } & -0.023648 & 0.011986 & -1.972974 & 0.0495 \\
\hline \hline R-squared & 0.051880 & Mean dependent var & 0.109603 \\
Adjusted R-squared & 0.045273 & S.D. dependent var & 0.127539 \\
S.E. of regression & 0.124619 & Akaike info criterion & -1.316822 \\
Sum squared resid & 4.457074 & Schwarz criterion & -1.278858 \\
Log likelihood & 193.9392 & Hannan-Quinn criter. & -1.301611 \\
F-statistic & 7.852211 & Durbin-Watson stat & 1.141058 \\
Prob(F-statistic) & 0.000478 & & & \\
\hline \hline
\end{tabular}

Sumber: Output Eviews, 2017

Hasil output dari regresi panel data dengan metode common effect (The Pooled OLS Method) dapat dilihat di tabel 4.6. Dari tabel diatas terdapat satu variabel dengan test individual $(\mathrm{t}$ test probability) terlihat signifikan dengan $\alpha=5 \%$ dan nilai adjustedR ${ }^{2}$ sebesar 0.045273 dengan nilai Durbin-Watson test sebesar 1.141058 yang rendah (jauh dari range angka 2) yang menandakan adanya masalah autokorelasi. Metode ini mengasumsikan bahwanilai intersep antar individual dianggap sama dimana hal ini merupakan asumsi yang sangat membatasi (restricted) (Gujarati, 2004). Sehingga metode pooled regression ini tidak dapat menangkap gambaran yang sebenarnya atas hubungan yang terjadi antara variabel bebas dengan variabel terikatnya, begitu juga dengan hubungan diantara tiap individu cross section. Begitu juga seperti yang dijabarkan pada metode pemilihan secara teoritis yang mengatakan bahwa metode common effect terlalu sederhana untuk mendeskripsikan fenomena yang ada. Oleh karena itu,hal yang perlu dilakukan ialah menemukan nature yang spesifik atas hubungan yang terjadi diantara masing - masing individu pada data cross section. Maka data diolah dengan menggunakan metode Fixed Effect.

Dari tabel 3 ini dapat dilihat bahwa jumlah variabel individu atas uji t-stat tidak ada yang memberikan hasil yang signifikan. Namun nilai adjusted $\mathrm{R}^{2}$ sebesar 0.513626 memberikan nilai cukup memuaskan. Nilai probability dari f-stat senilai 0.000000 memberikan artian bahwa model tersebut highly significant dengan nilai Durbin-Watson stat sebesar 2.721387 sudah pada range angka 2, yang menandakan tidak adanya masalah autokorelasi.

Tabel 3.Hasil Regresi dengan menggunakan panel least square model estimate fixed effect 


\begin{tabular}{|c|c|c|c|c|}
\hline Variable & Coefficient & Std. Error & $\mathrm{t}$-Statistic & Prob. \\
\hline $\mathrm{C}$ & 0.136942 & 0.011236 & 12.18782 & 0.0000 \\
\hline PL & -0.023317 & 0.008753 & -2.663989 & 0.0083 \\
\hline KAN & -0.007984 & 0.014241 & -0.560648 & 0.5756 \\
\hline \multicolumn{5}{|c|}{ Effects Specification } \\
\hline \multicolumn{5}{|c|}{$\begin{array}{l}\text { Cross-section fixed (dummy variables) } \\
\text { Period fixed (dum my variables) }\end{array}$} \\
\hline R-squared & 0.619652 & \multirow{7}{*}{\multicolumn{2}{|c|}{$\begin{array}{l}\text { Mean dependent var } \\
\text { S.D. dependent var } \\
\text { Akaike info criterion } \\
\text { Schwarz criterion } \\
\text { Hannan-Quinn criter. } \\
\text { Durbin-Watson stat }\end{array}$}} & 0.109603 \\
\hline Adjusted R-squared & 0.513626 & & & 0.127539 \\
\hline S.E. of regression & 0.088947 & & & -1.809527 \\
\hline Sum squared resid & 1.788001 & & & -0.999622 \\
\hline Log likelihood & 326.3813 & & & -1.485039 \\
\hline F-statistic & 5.844332 & & & 2.721387 \\
\hline Prob(F-statistic) & 0.000000 & & & \\
\hline
\end{tabular}

Sumber: Output Eviews, 2017

Setelah hasil dari model common effect dan fixed effect diperoleh maka selanjutnya dilakukan Uji Chow. Pengujian tersebut dibutuhkan untuk memilih model yang paling tepat diantara model common effect dan fixed effect. 
Tabel 4. Uji Chow

\begin{tabular}{lrrr}
\hline \hline Effects Test & Statistic & d.f. & Prob. \\
\hline \hline Cross-section F & 5.879820 & $(57,226)$ & 0.0000 \\
Cross-section Chi-square & 263.741312 & 57 & 0.0000
\end{tabular}

Sumber: Output Eviews, 2017

Hasil dari uji chow diatas menunjukkan bahwa Ho dengan model mengikuti model common effect ditolak. Dikarenakan hasil probabilitas lebih besar taraf signifikansi 0,05 (5\%), oleh karena itu model yang dipilih adalah model fixed effect. Untuk menentukan model regresi data panel yang tepat, selanjutnya

melakukan regresi dengan model random effect. Dimana, efek random digunakan untuk mengatasi kelemahan metode efek tetap (fixed effect) yang menggunakan variabel semu. Hasil dari regresi dengan menggunakan model random effect dapat dilihat pada tabel diatas.

Tabel 5. Hasil Regresi dengan menggunakan panel least square model estimate

\begin{tabular}{|c|c|c|c|c|}
\hline \multicolumn{5}{|c|}{ random effect } \\
\hline — Variable & Coefficient & Std. Error & t-Statistic & Prob. \\
\hline C & 0.142068 & 0.015783 & 9.001445 & 0.0000 \\
\hline PL & -0.027055 & 0.008585 & -3.151449 & 0.0018 \\
\hline KAN & -0.012225 & 0.011474 & -1.065444 & 0.2876 \\
\hline \multicolumn{5}{|c|}{ Effects Specification } \\
\hline & & & S.D. & Rho \\
\hline Cross-section random & & & 0.085515 & 0.4803 \\
\hline Period random & & & 0.000000 & 0.0000 \\
\hline Idios yncratic random & & & 0.088947 & 0.5197 \\
\hline \multicolumn{5}{|c|}{ Weighted Statistics } \\
\hline R-squared & 0.037318 & \multirow{5}{*}{\multicolumn{2}{|c|}{$\begin{array}{l}\text { Mean dependent var } \\
\text { S.D. dependent var } \\
\text { Sum squared resid } \\
\text { Durbin-Watson stat }\end{array}$}} & 0.046226 \\
\hline Adjusted R-squared & 0.030610 & & & 0.090602 \\
\hline S.E. of regression & 0.089204 & & & 2.283774 \\
\hline F-statistic & 5.562756 & & & 2.155770 \\
\hline Prob(F-statistic) & 0.004264 & & & \\
\hline
\end{tabular}

Sumber: Output Eviews, 2017

Baik pada tabel 4 yang menggunakan model fixed effect dan tabel 5 yang menggunakan model random effect, semuanya menunjukkan hasil variabel independen berpengaruh signifikan terhadap dependen yaitu arus kas masa depan. Namun peneliti belum dapat menentukan model mana yang akan gunakan. Oleh karena itu diperlukan uji Hausman untuk mengetahuinya. Pada tabel 6 disajikan hasil dari uji Hausman yang telah dilakukan dengan menggunakan Eviews 9.

Untuk menentukan apakah model Random effects atau Fixed effects yang digunakan, peneliti perlu membandingkan nilai Uji Hausman dengan nilai Chi-Squre. Dimana, nilai Chi-Square didapat dari Chi-Square tabel dengan nilai degree of freedom sebanyak independen variabel yaitu dua dengan menggunakan nilai signifikansi 5\% maka peneliti dapat memperoleh nilai 5.989 . 
Tabel 6. Uji Hausman

Correlated Random Effects - Hausman Test

Equation: Untitled

Test cross-section and period random effects

\begin{tabular}{lrrr}
\hline \hline Test Summary & Chi-Sq. Statistic & Chi-Sq. d.f. & Prob. \\
\hline \hline Cross-section random & 6.957644 & 2 & 0.0308
\end{tabular}

Sumber: Output Eviews, 2017

Jika hasil nilai uji Hausman lebih besar dari nilai Chi-Squre maka model yang digunakan adalah Fixed Effect, dan apabila sebaliknya yang terjadi nilai uji Hausman lebih kecil dari nilai kritisnya maka model yang digunakan adalah model Random Effect. Maka berdasarkan hasil uji Hausman yang tersaji pada tabel diatas, peneliti dapat mengambil keputusan untuk menggunakan model fixed effect, karena nilai Chi Squre yang dihasilkan dari uji Hausman lebih besar dari nilai Chi Squre tabel (6.958>5.989) dengan 2 degree of freedom (dua variabel independen).

\section{Hasil Uji Hipotesis 1}

\section{Tabel 7. Hasil Output Model Regresi}

\begin{tabular}{|c|c|c|c|c|}
\hline Variable & Coefficient & Std. Error & t-Statistic & Prob. \\
\hline C & 0.136942 & 0.011236 & 12.18782 & 0.0000 \\
\hline $\mathrm{PL}$ & -0.023317 & 0.008753 & -2.663989 & 0.0083 \\
\hline KAN & -0.007984 & 0.014241 & -0.560648 & 0.5756 \\
\hline \multicolumn{5}{|c|}{ Effects Specification } \\
\hline \multicolumn{5}{|c|}{$\begin{array}{l}\text { Cross-section fixed (dummy variables) } \\
\text { Period fixed (dummy variables) }\end{array}$} \\
\hline R-squared & 0.619652 & \multirow{6}{*}{\multicolumn{2}{|c|}{$\begin{array}{l}\text { Mean dependent var } \\
\text { S.D. dependent var } \\
\text { Akaike info criterion } \\
\text { Schwarz criterion } \\
\text { Hannan-Quinn criter. } \\
\text { Durbin-Watson stat }\end{array}$}} & 0.109603 \\
\hline Adjusted R-squared & 0.513626 & & & 0.127539 \\
\hline S.E. of regression & 0.088947 & & & -1.809527 \\
\hline Sum squared resid & 1.788001 & & & -0.999622 \\
\hline Log likelihood & 326.3813 & & & -1.485039 \\
\hline F-statis tic & 5.844332 & & & 2.721387 \\
\hline Prob(F-statistic) & 0.000000 & & & \\
\hline
\end{tabular}

Sumber: Output Eviews, 2017

Hipotesis 1 yang menyatakan bahwa persistensi laba memiliki pengaruh terhadap arus kas masa depan. Berdasarkan kajian teori yang telah dilakukan sebelumnya, persistensi laba diasumsikan memiliki pengaruh terhadap arus kas masa depan. Sehingga asumsi sementara pada penelitian ini berupa.

Berdasarkan hasil pengolahan data panel dengan metode OLS secara garis besar menunjukkan pengaruh langsung antara persistensi laba terhadap arus kas masa depan, sebagaimana nampak dalam tabel diatas. Dilihat dari tabel diatas menunjukkan adanya pengaruh signifikan antara persistensi laba terhadap arus kas masa depan dengan t-statistic sebesar -2.663989 dengan nilai Probabilitas sebesar $0.0083<0.05$, sehingga pada penelitian ini $\mathrm{H}_{1}$ diterima.

\section{Hasil uji hipotesis 2}

Hasil hipotesis 2 yang menyatakan bahwa Komponen akrual neraca memiliki pengaruh terhadap arus kas masa depan. Berdasarkan kajian teori yang telah dilakukan sebelumnya, 
komponen akrual diasumsikan memiliki pengaruh terhadap arus kas masa depan. Berdasarkan hasil dalam tabel 6 diatas, tidak terdapat pengaruh signifikan antara komponen akrual neraca terhadap arus kas masa depan dengan t-statistic sebesar -0.560648 dengan nilai Probabilitas sebesar $0.575>0.05$, sehingga pada penelitian ini $\mathrm{H}_{2}$ ditolak. Hasil penelitian ini menunjukan bahwa komponen akrual neraca yang terdiri dari piutang, persediaan dan utang secara bersama-sama tidak dapat mempengaruhi arus kas masa depan.

\section{Uji Tambahan}

Komponen akrual (perubahan piutang dan perubahan persediaan) terhadap arus kas masa depan

Dilihat dari hasil hipotesis ke 2 yang menyatakan bahwa komponen akrual yang terdiri atas perubahan piutang, perubahan persediaan dan perubahan hutang yang diuji secara simultan (bersama) menunjukan hasil yang tidak signifikan. Peneliti mencoba melakukan uji tambahan untuk menguji variabel yang ada didalam komponen akrual secara parsial. Pengujian pertama yaitu dengan menggabungkan total dari perubahan piutang dan perubahan persediaan. Hasilnya diperoleh dalam table berikut.

Tabel 9. Hasil OutputModel Pegujian 1

\begin{tabular}{crrrr}
\hline \hline Variable & Coefficient & Std. Error & t-Statistic & Prob. \\
\hline \hline C & 0.111108 & 0.007750 & 14.33599 & 0.0000 \\
KAN & -0.041377 & 0.032129 & -1.287829 & 0.1991 \\
\hline \hline
\end{tabular}

Sumber: Output Eviews, 2017

Dilihat dari tabel 9 diatas menunjukkan tidak adanya pengaruh signifikan antara komponen akrual neraca terhadap arus kas masa depan dengan t-statistic sebesar -1.287 dengan nilai Probabilitas sebesar 0.199>0.05, sehingga pada penelitian ini ditolak. Hasil penelitian ini menunjukan bahwa komponen akrual neraca yang terdiri dari perubahan piutang dan perubahan persediaan secara bersama-sama tidak dapat mempengaruhi arus kas masa depan. Dengan demikian, komponen akrual perubahan piutang dan perubahan persediaan tidak dapat digunakan untuk memprediksi arus kas masa depan.

Komponen akrual (perubahan piutang dan perubahan hutang ) terhadap arus kas masa depan

Tabel 8. Hasil Output uji tambahan 2 


\begin{tabular}{|c|c|c|c|c|}
\hline Variable & Coefficient & Std. Error & $\mathrm{t}$-Statis tic & Prob. \\
\hline $\begin{array}{l}\mathrm{C} \\
\text { KAN }\end{array}$ & $\begin{array}{r}0.121712 \\
-0.159252\end{array}$ & $\begin{array}{l}0.008402 \\
0.049309\end{array}$ & $\begin{array}{r}14.48644 \\
-3.229671\end{array}$ & $\begin{array}{l}0.0000 \\
0.0014\end{array}$ \\
\hline \multicolumn{5}{|c|}{ Effects Specification } \\
\hline \multicolumn{5}{|c|}{$\begin{array}{l}\text { Cross-section fixed (dummy variables) } \\
\text { Period fixed (dummy variables) }\end{array}$} \\
\hline $\begin{array}{l}\text { R-squared } \\
\text { Adjusted R-squared } \\
\text { S.E. of regression } \\
\text { Sum squared resid } \\
\text { Log likelihood } \\
\text { F-statistic } \\
\text { Prob(F-statistic) }\end{array}$ & $\begin{array}{r}0.208358 \\
-0.007861 \\
0.128040 \\
3.721479 \\
220.0930 \\
0.963641 \\
0.556898\end{array}$ & \multicolumn{2}{|c|}{$\begin{array}{l}\text { Mean dependent var } \\
\text { S.D. dependent var } \\
\text { Akaike info criterion } \\
\text { Schwarz criterion } \\
\text { Hannan-Quinn criter. } \\
\text { Durbin-Watson stat }\end{array}$} & $\begin{array}{r}0.109603 \\
0.127539 \\
-1.083400 \\
-0.286150 \\
-0.763982 \\
2.350613\end{array}$ \\
\hline
\end{tabular}

Sumber: Output Eviews, 2017

Dilihat dari tabel diatas menunjukkan adanya pengaruh signifikan antara komponen akrual neraca terhadap arus kas masa depan dengan t-statistic sebesar -3.229 dengan nilai Probabilitas sebesar $0.0014<0.05$, sehingga pada hasil uji penelitian ini diterima. Hasil penelitian ini menunjukan bahwa komponen akrual neraca yang terdiri dari perubahan piutang dan perubahan hutang secara bersama-sama dapat mempengaruhi arus kas masa depan. Dengan demikian, komponen akrual perubahan piutang dan perubahan hutang dapat digunakan untuk memprediksi arus kas masa depan.

\section{Komponen Akrual Neraca (Perubahan Persediaan dan Perubahan Hutang) terhadap Arus Kas Masa Depan}

Tabel 9. Hasil Output uji tambahan 3

\begin{tabular}{|c|c|c|c|c|}
\hline Variable & Coefficient & Std. Error & t-Statistic & Prob. \\
\hline$\stackrel{\mathrm{C}}{\mathrm{KAN}}$ & $\begin{array}{r}0.118243 \\
-0.105953\end{array}$ & $\begin{array}{l}0.008148 \\
0.037354\end{array}$ & $\begin{array}{r}14.51250 \\
-2.836495\end{array}$ & $\begin{array}{l}0.0000 \\
0.0050\end{array}$ \\
\hline \multicolumn{5}{|c|}{ Effects Specification } \\
\hline \multicolumn{5}{|c|}{$\begin{array}{l}\text { Cross-section fixed (dummy variables) } \\
\text { Period fixed (dum my variables) }\end{array}$} \\
\hline $\begin{array}{l}\text { R-squared } \\
\text { Adjusted R-squared } \\
\text { S.E. of regression } \\
\text { Sum squared resid } \\
\text { Log likelihood } \\
\text { F-statistic } \\
\text { Prob(F-statistic) }\end{array}$ & $\begin{array}{r}0.200325 \\
-0.018088 \\
0.128688 \\
3.759241 \\
218.6291 \\
0.917182 \\
0.649346\end{array}$ & \multicolumn{2}{|c|}{$\begin{array}{l}\text { Mean dependent var } \\
\text { S.D. dependent var } \\
\text { Akaike info criterion } \\
\text { Schwarz criterion } \\
\text { Hannan-Quinn criter. } \\
\text { Durbin-Watson stat }\end{array}$} & $\begin{array}{r}0.109603 \\
0.127539 \\
-1.073304 \\
-0.276054 \\
-0.753886 \\
2.342463\end{array}$ \\
\hline
\end{tabular}

Sumber: Output Eviews, 2017

Dilihat dari tabel 9. Diatas menunjukkan bahwa terdapat pengaruh signifikan antara komponen akrual neraca terhadap arus kas masa depan dengan t-statistic sebesar -2.836 dengan nilai Probabilitas sebesar $0.0050<0.05$, sehingga pada hasil uji penelitian ini diterima. Hasil penelitian ini menunjukan bahwa komponen akrual neraca yang terdiri dari perubahan persediaan dan perubahan hutang secara bersama-sama dapat mempengaruhi arus kas masa depan. Dengan demikian, komponen akrual perubahan persediaan dan perubahan hutang dapat digunakan untuk memprediksi arus kas masa depan. 


\section{E. Kesimpulan dan Saran}

Berdasarkan hasil penelitian yang telah diuraikan sebelumnya, penelitian ini dapat melaporkan bahwa persistensi laba berpengaruh positif dan signifikan terhadap arus kas masa depan. Hal ini mengindikasikan bahwa laba yang persisten dapat digunakan untuk mempredikasi arus kas masa depan.

Hasil lainnya menunjukkan bahwa komponen akrual neraca yang terdiri atas perubahan piutang, perubahan persediaan dan perubahan hutang, tidak berpengaruh terhadap arus kas masa depan. Hal ini mengindikasikan bahwa komponen akrual neraca tidak dapat digunakan untuk memprediksi arus kas masa depan. Sedangkan, berdasarkan hasil uji tambahan menunjukkan bahwa komponen akrual neraca dengan hanya menggabungkan total perubahan piutang dan perubahan persediaan secara bersama tidak mempengaruhi arus kas masa depan. Artinya arus kas masa depan tidak dapat diprediksi dengan komponen akrual neraca, jika hanya menggabungkan perubahan piutang dengan perubahan persediaan.

Hasil uji berikutnya melaporkan bahwa gabungan dari perubahan piutang dengan perubahan hutang secara bersama berpengaruh signifikan. Artinya, arus kas masa depan dapat diprediksi dengan komponen akrual neraca dengan menggunakan perubahan piutang dan perubahan hutang. Terakhir peneliti melakukan pengujian dengan menggabungkan total dari perubahan persediaan dan perubahan hutang secara bersama yang hasil menunjukkan pengaruh yang signifikan. Artinya, arus kas masa depan dapat diprediksi dengan komponen akrual berupa perubahan persediaan dan perubahan hutang.

\section{Saran}

Berdasarkan kesimpulan di atas, maka penulis dapat memberikan saran untuk peneliti selanjutnya, yaitu pertama, peneliti selanjutnya diharapkan dapat menambahkan rentang waktu pengamatan dan menambah variabel independent untuk meningkatkan akurasi penelitian serta menambah objek penelitian, tidak hanya pada perusahaan manufaktur saja, karena memungkinkan ditemukan hasil yang berbeda jika dilakukan pada objek yang berbeda. Kedua, bagi investor dan calon investor dipasar modal perlu memperhatikan kualiatas dari laba, yang dapat diukur dari laba tahun berjalan dengan laba tahun lalu. Karena laba yang berkualitan menunjukan laba yang persisten dan hal tersebut terbukti mempengaruhi arus kas masa depan.

\section{F. Daftar Referensi}

Andayani, Rai Dwi \& I Gede Ary Wirajaya. (2015). Kemampuan laba, arus kas operasi dalam memprediksi arus kas masa depan. E-jurnal akuntansi Universitas Udanaya 10.3.882-896.

Baridwan, Zaki.(2004). Intermedit Accounting, Edisi Kedelapan. Yogyakarta: BPFE.

Barth, et.al. (2001). Financial Analysts and The Pricing of Accruals. Working Papper. Research paper series, Graduated School of Bussiness Stanford University. 
Dechow, et.al. (1998). The Quallity of Accrual and Earnings: The Role of Accruals Estimation Errors. The Accounting Review, 77 (Supplement), 35-39.

Ebaid, Ibrahim El-Sayed. (2010). Accrual and the prediction of future cash flows, Management Reasearch, Vol. 34 No. 7, pp. 838-853.

Francis, J. et.al. (2004). Cost of equity and Earnings attributes. The Accounting Review79 (4): 967-1010.

Ghozali, Imam. (2013). Aplikasi analisis multivariate dengan program ibm spss Edisi Tujuh. Semarang: Badan Penerbit Universitas Diponegoro

Gujarati, Damodar N. (2009). Dasar-dasar Ekonometrika, Buku 1, Edisi 5. Jakarta: Salemba Empat.

Harapan, Sofyan Sayfri. (2010). Teori Akuntansi Laporan Keuangan. Jakarta: Bumi Aksara.

Hayn, C. (1995). The Information Content of Losses. Journal of Accounting and Economics, 20, 125-153. ISSN: 2302-8556.

Kieso, Donald E., Jerry J. Weygandt, Terry D Warfield. (2008). Akuntansi intermediate jilid 1. Jakarta: Erlangga.

Penman. (2009). Financial Statement Analysis and Security Valuation. Four Edition. Singapore: McGRAW-HILL

Prayoga, Irfan Bagus Dwi. 2012. Pengaruh laba bersih dan komponen-komponen akrual terhadap arus kas aktivitas operasi di masa depan. Fakultas Ekonomi dan Bisnis. Universitas Diponegoro.

Sccott, W. R. (2009). Financial Accounting Theory. Fifth Edision. Prentice-Hall International, Inc.

Situs resmi Bursa Efek Indonesia. (2017). www.idx.co.id. Diakses tanggal 10April 2017.

Sloan, R. G. (1996). Do Stock Prices Fully Reflect Information in Accruals and Cash Flows about Future Earning? The Accounting Review 71 (July), pp 289-315.

Spence, M. (2009). Job Market Signaling. The Quartely Journal of Economic, Vol.87 (No.3): 355-374.

Subramanyam, Wild, Jhon. J, K.R. (2014). Analisis laporan keuangan buku 1, Edisi ke 8, Jakarta: Salemba Empat.

Sugiyono. (2015). Metode penelitian kuantitatif, kualitatif $r \& d$. Bandung: Alfabeta.

Sulistyawan, Wahyu \& Aditya Septiani. (2015). Pengaruh laba bersih, arus kas operasi dan komponen-komponen akrual dalam memprediksi arus kas operasi di masa depan. Diponegoro Journal of Accounting, Vol. 4, No. 4, Hlm. 1-11. 
Triyono. (2011). Dampak Kualitas Laba Terhadap Kemampuan Prediksi Laba, Arus Kas, dan Komponen Akrual. Simposium Nasional Akuntansi XIV. Aceh: Universitas Syiah Kuala Banda Aceh.

Tucker, Jennifer W. dan Paul A Zarowin. (2006). Does Income Smoothing Improve Earnings Informativeness?. The Accounting Review, 81 (1), hal. 251-270.

Winarno, Wing Wahyu. (2011). Analisis Ekonometrika dan Statistika dengan Eviews. Yogyakarta: BPFE. 